Georgia State University

ScholarWorks @ Georgia State University

\title{
Employer Monopsony Power in the Labor Market for Undocumented Workers
}

Julie L. Hotchkiss

Federal Reserve Bank of Atlanta, julie.I.hotchkiss@atl.frb.org

Myriam Quispe-Agnoli

Federal Reserve Bank of Atlanta, myriam.quispe-agnoli@atl.frb.org

Follow this and additional works at: https://scholarworks.gsu.edu/uwrg_workingpapers

\section{Recommended Citation}

Hotchkiss, Julie L. and Quispe-Agnoli, Myriam, "Employer Monopsony Power in the Labor Market for Undocumented Workers" (2009). UWRG Working Papers. 145.

https://scholarworks.gsu.edu/uwrg_workingpapers/145

This Article is brought to you for free and open access by the Usery Workplace Research Group at ScholarWorks @ Georgia State University. It has been accepted for inclusion in UWRG Working Papers by an authorized administrator of ScholarWorks @ Georgia State University. For more information, please contact scholarworks@gsu.edu. 
Working Paper 2009-4-3

April 2009

\section{Employer Monopsony Power in the Labor Market for Undocumented Workers}

Julie Hotchkiss

Federal Reserve Bank of Atlanta

Myriam Quispe-Agnoli

Federal Reserve Bank of Atlanta 


\section{Employer Monopsony Power in the}

Labor Market for Undocumented Workers

Julie L. Hotchkiss and Myriam Quispe-Agnoli

Working Paper 2009-14

April 2009

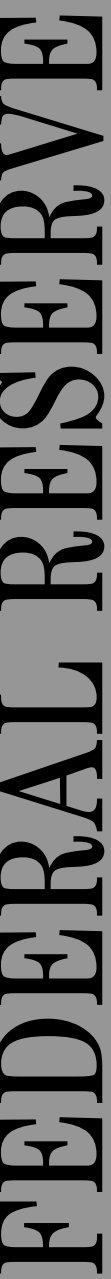




\title{
Employer Monopsony Power in the Labor Market for Undocumented Workers
}

\author{
Julie L. Hotchkiss and Myriam Quispe-Agnoli
}

\section{Working Paper 2009-14 April 2009}

\begin{abstract}
Using matched employer-employee data from the state of Georgia, this paper investigates the potential for employer monopsony power in the labor market for undocumented workers. We find that the labor supply elasticity of undocumented workers is about 13 percent lower than that estimated for documented workers, suggesting that at least some of the observed wage gap between documented and undocumented workers can be explained by firms' exploiting their monopsony power. There is also evidence of some displacement, with the hiring of undocumented workers being associated with a small amount of documented worker separation.
\end{abstract}

JEL classification: J42, J61, J2

Key words: labor demand, monopsony, illegal immigration, undocumented workers

J. David Brown, Curtis Flores, Gordon Hanson, Federico Mandelman, Pia Orrenius, Eric Smith, Dan Waggoner, and Madeline Zavodny provided helpful comments. The authors thank Nicole Baerg, Gustavo Canavire, M. Laurel Graefe, and Gustavo Uceda for research assistance. The views expressed here are the authors' and not necessarily those of the Federal Reserve Bank of Atlanta or the Federal Reserve System. Any remaining errors are the authors' responsibility.

Please address questions regarding content to Julie Hotchkiss (contact author), Research Department, Federal Reserve Bank of Atlanta, 1000 Peachtree Street, N.E., Atlanta, GA 30309-4470, 404-498-8198, julie.l.hotchkiss@atl.frb.org, or Myriam QuispeAgnoli, Research Department, Federal Reserve Bank of Atlanta, 1000 Peachtree Street, N.E., Atlanta, GA 30309-4470, 404-4988930, myriam.quispe-agnoli@atl.frb.org.

Federal Reserve Bank of Atlanta working papers, including revised versions, are available on the Atlanta Fed's Web site at www.frbatlanta.org. Click "Publications" and then "Working Papers." Use the WebScriber Service (at www.frbatlanta.org) to receive e-mail notifications about new papers. 


\section{Employer Monopsony Power in the Labor Market for Undocumented Workers}

\section{$\underline{\text { I. Introduction and Background }}$}

The model of monopsonistic discrimination was developed by Robinson (1933) to describe a labor market in which two groups of equally productive workers (men and women) are paid different wages because they differ in their elasticities of labor supply. Robinson theorized that women were paid less than men because they were limited in their alternative labor market options as a result of their husbands' employment situations. The source of the firm's monopsonistic power in the labor market derives from the behavior of workers, not from the degree of competition in the firm's product market. In other words, the presence of a large number of competitive firms does not preclude monopsonistic discrimination. In fact, a greater degree of product market competition will put additional pressures on an employer to take advantage of differential labor supply elasticities across workers. ${ }^{1}$ The purpose of this paper is to use a unique employer-employee matched data set to determine whether there is any empirical evidence of employers practicing monopsonistic discrimination against undocumented workers. If such evidence is found, it suggests that tighter restrictions on illegal immigration will raise production costs of firms and likely prices paid by consumers. The analysis also has implications for potential employer opposition to tighter immigration policies.

The presence of monopsonistic employer power has been identified in a number of settings. Evidence of potential monopsonistic discrimination against women as a result of lower labor supply elasticities (relative to men) is provided by Hirsch et al. (2006) and Barth and DaleOlsen (1999). ${ }^{2}$ Scully (1989) and Zimbalist (1992) provide evidence of monopsonistic

\footnotetext{
${ }^{1}$ See Bhaskar et al. (2002), page 167.

${ }^{2}$ See Ofek and Merrill (1997) for empirical evidence of women facing fewer employment opportunities as a result of being geographically constrained by their husband's employment choices.
} 
discrimination (at least through the 1980s) in baseball for players that are contractually limited in their employment options by being tied to one team before achieving free-agent status. Scott et al. (1985) offer similar evidence for basketball players. In the case where workers are divided and one group is paid less than an equally productive different group, Lang et al. (2005) present a theoretical model in which monopsonistic labor market outcomes can arise in equilibrium and does not necessarily require firms to overtly discriminate against the lower-paid group. It only requires that the disadvantaged group think employers are discriminatory. They offer this model as explanation for the persistent wage gap between black and white workers. ${ }^{3}$ The labor market for undocumented workers meets the classic conditions in which employers can be successful in practicing monopsonistic discrimination--identifiable characteristics on which groups of workers can be segmented, and one of the groups of workers being limited in their employment opportunities.

First of all, documented and undocumented workers in the U.S. are believed to be distinguishable from one another without much effort. The Department of Homeland Security estimates for January 2008 that 61 percent of unauthorized immigrants come from Mexico (Hoefer et al. 2009). Clearly not all Hispanic individuals are undocumented, but, in the absence of time consuming document verification, ethnicity and language proficiency may be used by employers as a proxy for their best guess of whether a worker is undocumented. Second, for fear of being deported, undocumented workers are likely unwilling to complain about low wages or poor employment environments. It is also not unreasonable to expect that the more employers to which undocumented workers expose themselves, the higher the risk of deportation. And indeed, it is likely that there are many firms who will simply refuse to hire undocumented

\footnotetext{
${ }^{3}$ Raphael and Riker (1999) offer empirical evidence for the role geographic mobility plays in limiting the employment opportunities of blacks, thus contributing to observed racial wage differentials.
} 
workers or that undocumented workers are geographically constrained by the support (or lack) of social networks. All of these factors reduce employment opportunities of undocumented workers, ceteris paribus. Stark (2007) presents a compelling theoretical mechanism through which the work effort of undocumented workers is increased as their probability of deportation increases, which, in turn expands the wedge between undocumented worker productivity and their wage. Semple (2008) offers anecdotal evidence that undocumented workers are at the mercy of their employers. An undocumented worker reported to Semple that an employer refused to pay him about $\$ 1,000$ he was owed for work performed, but that, "fear [of being deported] kept my mouth shut."

Very little empirical investigation of the labor market experiences of undocumented workers exists. DeFreitas (1988) and Hotchkiss and Quispe-Agnoli (2009) investigate the wage impact of the presence of undocumented workers, finding modest impacts that vary across worker skill level and across sectors. Brown et al. (2008) presents evidence that employing undocumented workers gives firms a fairly significant competitive advantage, suggesting that the lower wages paid to undocumented workers likely derives from a monopsonistic position of the employer, rather than making up for lower productivity of the workers. This paper estimates labor supply elasticities for documented and undocumented workers, finding evidence that undocumented workers are less sensitive to wages than their documented co-workers. There is also modest evidence of displacement of documented workers as more undocumented workers arrive, although the analysis is not able to distinguish between voluntary and involuntary displacement effects. 


\section{The Data}

The primary data used for the analyses in this paper are the Employer File and the Individual Wage File, compiled by the Georgia Department of Labor for the purposes of administering the state's Unemployment Insurance (UI) program. These data are highly confidential and strictly limited in their distribution. The data are available from the first quarter of 1990 through the fourth quarter of 2006. The Employer File provides an almost complete census of firms in the U.S., covering approximately 99.7 percent of all wage and salary workers (Committee on Ways and Means 2004). ${ }^{4}$ The establishment-level information includes the number of employees, the total wage bill, and the NAICS classification of each establishment. The Individual Wage File, which links individual workers to their employer, is used to construct workforce characteristics at the firm level, such as workforce churning and the share of new hires that is undocumented. We take advantage of the longitudinal nature of the data to calculate the firm's age, turnover rates, and worker tenure. The data also contain a 6-digit NAICS industry code and the county of location, allowing us to construct or merge in industry- and county-level indicators, such as county unemployment rate.

Regrettably, the data set contains no information about workers' demographics or, more importantly, immigration status. However, again making use of the longitudinal nature of the data, we estimate an individual fixed-effects model, allowing us to control for individual characteristics that do not vary over time (e.g., innate human capital, immigration status).

\section{A. Identifying Invalid Social Security Numbers}

Every quarter employers must file a report with their state's Department of Labor detailing all wages paid to workers who are covered under the Social Security Act of 1935. Each

\footnotetext{
${ }^{4}$ Certain jobs in agriculture, domestic services, non-profit organizations are excluded from UI coverage and, therefore these workers are not included in the data (Committee on Ways and Means 2004). For information about which workers are covered, see U.S. Department of Labor (2008).
} 
worker on this report is identified by his/her social security number (SSN). There are a number of ways in which one can establish that a reported social security number is invalid. The Social Security Administration provides a service by which an employer can upload a file of SSNs for checking, but one must register as an employer to obtain this service. ${ }^{5}$ In addition, there are several known limitations on what can be considered a valid social security number, so a simple algorithm is used to check whether each number conforms to the valid parameters.

There are three pieces to a SSN. ${ }^{6}$ The first three numbers are referred to as the Area Number. This number is assigned based on the state in which the application for a SSN was made; it does not necessarily reflect the state of residence. The lowest Area Number possible is 001 and the highest Area Number ever issued, as of December 2006, is 772. Using information provided by the SSA, the dates at which area numbers between 691 and 772 are first assigned can be determined. Any SSN with an Area Number equal to 000, greater than 772, or which shows up before the officially assigned date, will be considered invalid.

The second piece of a SSN consists of the two-digit Group Number. The lowest group number is 01 , and they are assigned in non-consecutive order. Any SSN with a Group Number equal to 00 or with a Group Number that appears in the data out of sequence with the Area Number will be considered invalid.

The last four digits of a SSN are referred to as the Serial Number. These are assigned consecutively from 0001 to 9999. Any SSN with a Serial Number equal to 0000 is invalid.

In 1996 the Internal Revenue Service (IRS) introduced the Individual Tax Identification Number (ITIN) to allow individuals who had income from the U.S. to file a tax return (the first

\footnotetext{
${ }^{5}$ See Social Security Number Verification Service <http://www.ssa.gov/employer/ssnv.htm>.

${ }^{6}$ Historical information and information about valid SSNs can be found at the Social Security Administration's web sites: <http://www.ssa.gov/history/ssn/geocard.html>, <http://www.xocialsecurity.gov/employer/stateweb.htm>, and <http://www.socialsecurity.gov/employer/ssnvhighgroup.htm $>$.
} 
ITIN was issued in 1997). It is simply a "tax processing number," and does not authorize an individual to work in the U.S. Employers are instructed by the IRS to "not accept an ITIN in place of a SSN for employee identification for work. An ITIN is only available to resident and nonresident aliens who are not eligible for U.S. employment and need identification for other tax purposes." 7 ITIN numbers have a "9" in the first digit of the Area Number and a "7" or "8" in the first digit of the Group Number. Anyone with this numbering scheme will be identified as having an invalid Area Number, as they are not authorized to work. The percent of SSN with high area numbers that also match the ITIN numbering scheme has risen from about one percent in 1997 to over 60 percent by the end of 2006. Identifying undocumented workers with ITIN numbers will be important in the fixed-effects estimation described below.

A series of SSNs were de-commissioned by the Social Security Administration because they had been put on fake Social Security Cards used as props to sell wallets. ${ }^{8}$ Apparently, some people who purchased the wallets thought the fake Social Security Cards were real and started using them as their own. If any of these 21 "pocketbook" SSNs appear in the data, they are considered invalid, although their frequency is so low as to be inconsequential. In addition, a number of SSNs are exactly equal to the employer identification number. These are invalid, primarily because they have too few digits. In any instance where a SSN is used for more than one person on a firm's UI wage report or does not have the required number of digits (including zeros), the SSN is considered invalid.

The possibility that someone fraudulently uses a valid SSN assigned to someone else poses a special problem. First of all, the SSN will show up multiple times across firms in one quarter for workers with different surnames (the wage report includes the first three characters of

\footnotetext{
7 "Hiring Employees," <http://www.irs.gov/businesses/small/article/0,id=98164,00.html>. Also see, "Individual Taxpayer Identification Number (ITIN)," <http://www.irs.gov/individuals/article/0,,id=96287,00.html> .

${ }^{8}$ See U.S. Department of Housing and Urban Development (1990).
} 
the workers' surnames). With this information alone, it is not possible to know which worker is using the SSN fraudulently and who the valid owner of the number is. If one of the SSN/surname pairs shows up in the data initially in a quarter by itself, this is the pair that is considered valid and all other duplicates (with different surnames) are considered invalid.

\section{B. Does "Invalid" mean "Undocumented?"}

Not all invalid SSN are classified as undocumented workers; examining the patterns of incidence of different types of invalid SSNs suggests that some types are firm generated rather than worker generated. Figure 1 illustrates the incidence patterns across types of invalid SSNs in construction. This pattern is consistently found in the other sectors as well. The percent of workers with SSNs having a high area number or out-of-sequence group number displays the expected growth in undocumented workers (see Hoefer et al. 2007), whereas the incidence of SSNs for other reasons exhibits a flat to declining, highly seasonal pattern. The strong seasonal nature of the other invalid reasons suggests that firms are temporarily assigning invalid SSN numbers to workers before having time to gather the information for the purpose of record keeping/reporting. Or, firms may decide to not bother obtaining a SSN for workers who will only be employed a very short time. ${ }^{9}$ The high degree of churning observed among workers with invalid SSNs for these other reasons is consistent with either of these practices. ${ }^{10}$

\section{[Figure 1 here]}

Since there is no way to know whether a temporary assignment by the firm of an invalid SSN is to merely cover for temporary employment of an undocumented worker or to allow the firm to file its wage report before having had a chance to record the worker's valid SSN, the

\footnotetext{
${ }^{9}$ Indeed, a worker has 90 days to resolve a discrepancy that results in the receipt of a "no-match" letter from the Social Security Administration. The employee may be long gone before such a letter is even received.

${ }^{10}$ The average churning rates for SSNs with invalid area numbers, invalid group numbers, duplicate SSNs with different surnames, and invalid for other reasons are $26.9 \%, 55.7 \%, 188.3 \%$, and 215.6\%, respectively.
} 
analysis below takes the conservative tack by considering as undocumented only those workers whose SSNs are classified as invalid because the area number is too high or the group number is assigned out of sequence. This will clearly undercount the actual number of undocumented workers, so that any effect identified in the analysis will also likely under-estimate the true effect of the presence of undocumented workers on firm exit. We take pains, however, to not include workers with invalid SSNs for these other reasons in the construction of worker characteristics among workers with valid SSNs. However, they are included in counts of aggregate firm employment.

Figure 2 plots the prevalence of undocumented workers in the six broadly defined sectors with the highest incidences. ${ }^{11}$ The concentration of workers in these sectors was also identified nationally by Fortuny et al. (2007). ${ }^{12}$ The pattern of growth is also consistent with Fortuny et al. who estimate that 72 percent of unauthorized immigrants in Georgia arrived in the last 10 years.

[Figure 2 here]

Fortuny et al. (2007) estimate that 4.5 percent of the workforce in Georgia was undocumented in 2004. In our sample 1.2 percent of workers are classified as undocumented in 2004. The implication is that the sample used for the analysis in this paper is capturing at least 26 percent of all undocumented workers in the state of Georgia. This is a respectable representation, given that to be included in the sample an undocumented worker must be reported by the employer to the Department of Labor in the first place, and that we are being very conservative in the identification of workers as undocumented.

\footnotetext{
${ }^{11}$ Agriculture is excluded from the graph for display purposes; the pattern of employment is considerably more seasonal and the percent of workers that is undocumented in agriculture reached just under six percent by 2006. ${ }^{12}$ Fortuny et al. (2007) estimate that nationally in 2004 the percent of workers in leisure and hospitality and construction that was undocumented was 10 percent each, nine percent of workers in agriculture, and six percent each in manufacturing, professional and business services, and other services.
} 


\section{Are Undocumented Workers Correctly Identified?}

It is crucial to establish confidence in the mechanism employed to identify undocumented workers. The Department of Homeland Security estimates for January 2008 that 61 percent of unauthorized immigrants come from Mexico (Hoefer et al. 2009). Clearly not all Hispanic individuals are unauthorized immigrants, but a first test of the accuracy of identifying undocumented workers might be to compare the geographic distribution of those identified as undocumented for the purposes of analysis in this paper and the geographic distribution of various ethnic and racial groups across counties in the state. Table 1 presents these correlation coefficients for 2005.

[Table 1 here]

The correlation between the percent of the county population that is Hispanic and the percent of workers in the county identified as undocumented is 0.18 (of course, some individuals may live and work in different counties). The correlations with the percent that is Asian and the percent that is African American in the counties are both negative. The correlation of the percent of firms in the county employing undocumented workers with ethnicity is also positive and highest as it relates the percent of the county population that is Hispanic (0.38). The correlation of the presence of these firms with percent of the county population that is Asian is also positive, but smaller at 0.27; the correlation with the percent of the population that is African American is again negative.

Additionally, the rate of growth seen in both the number and percent of undocumented workers identified in Georgia matches closely the rate of growth in the Social Security Administration's (SSA) earnings suspense file (ESF). The ESF is a repository of social security taxes paid by employers that cannot be matched to a valid name or SSN. It is widely believed 
that this growth in the ESF reflects growing incidence of unauthorized work in the U.S. (Bovbjerg 2006).

Figure 3 plots the number of workers identified (panel a) and the percent of workers identified (panel b) as undocumented along with the size of the ESF. This figure shows a remarkable consistency between the growth seen in workers identified as undocumented and the ESF. Payments on wages in the ESF reflect only about four percent of all initial non-matching earnings reports (the others were resolved through an error identification process). In addition, about 43 percent of employers associated with wage payments that end up in the ESF come from only five of 83 broad industry classifications, with eating and drinking establishments (leisure and hospitality, 17 percent) and construction (10 percent) being the largest contributors (Bovbjerg 2006).

[Figure 3 here]

The positive correlation between the Hispanic population across counties in Georgia and the percent of workers identified as undocumented for this analysis, as well as closely matching growth in undocumented workers identified in Georgia and growth in the SSA ESF independently suggest that the mechanism employed in this paper to identify undocumented workers is accurate.

\section{Sample Means}

For reasons discussed below, the analysis is constrained to include workers only between 1995 and 2000 inclusive. Table 2 presents some means for this sample of workers. In addition, the table contains means for an even smaller sub-set of undocumented workers whose SSN numbers follow the number scheme of ITIN numbers; this sample is only valid starting in 1997, when the first ITIN number was issued. 
[Table 2 here]

Documented workers earn 50 percent more, on average, than undocumented workers. Some of this wage differential could be because of the concentration of undocumented workers in lower-paying industries or occupations, undocumented workers working fewer hours, or the upward push in the occupational chain of documented workers with the arrival of lower-skilled undocumented workers (Pedace 2006). ${ }^{13}$ The undocumented wage gap increases as workers move up the wage distribution.

Undocumented workers are likely to have been on their current job a shorter amount of time and reflect greater separation behavior (not holding anything else constant). Undocumented workers appear to be concentrated among smaller employers who experience a greater degree of churning among its documented workforce, suggesting a need for workforce flexibility, as has been documented among firms that employ undocumented workers (Morales 1983-1984). The smaller firm size could be reflecting the typical size of firms in industries more likely to hire undocumented workers. The higher share of new hires that is undocumented among the undocumented sample suggests that undocumented workers are concentrated in certain industries.

There are some notable differences in the distribution of workers across industry skill intensity and NAICS classification. ${ }^{14}$ Most notably, undocumented workers are more concentrated in agriculture, construction, and leisure and hospitality. Interestingly, undocumented workers using ITIN numbers are more similarly distributed across industry skill intensity relative to documented workers than all undocumented workers are.

\footnotetext{
${ }^{13}$ The magnitude of the wage penalties is consistent with the finding by Rivera-Batiz (1999) that legal immigrants earn about 42 percent more than illegal immigrants.

${ }^{14}$ Appendix B describes the construction of skill classifications.
} 


\section{Theoretical and Empirical Framework}

\section{A. Elasticities of Separation}

Appealing to a simple version of the standard search problem and assuming that workers are more willing to work for firms paying higher wages, the following separation rates for documented and undocumented workers can be derived: ${ }^{15}$

$$
\begin{aligned}
& \mathrm{S}^{\mathrm{d}}\left(\mathrm{w} ; \mathrm{F}^{\mathrm{d}}[\mathrm{w}]\right)=\delta+\lambda^{\mathrm{d}}\left(1-\mathrm{F}^{\mathrm{d}}[\mathrm{w}]\right) \\
& \mathrm{S}^{\mathrm{u}}\left(\mathrm{w} ; \mathrm{F}^{\mathrm{u}}[\mathrm{w}]\right)=\delta+\lambda^{\mathrm{u}}\left(1-\mathrm{F}^{\mathrm{u}}[\mathrm{w}]\right)
\end{aligned}
$$

where $\mathrm{S}^{\mathrm{k}}$ is the separation rate of documented $(k=d)$ and undocumented $(k=u)$ workers; $\delta$ is the job destruction rate, assumed to be the same for documented and undocumented workers; and $\lambda^{\mathrm{k}}$ is the job offer arrival rate for documented and undocumented workers. The mere presence of some firms that will not hire undocumented workers means the offer arrival rate is lower for undocumented workers than for documented workers, $\lambda^{\mathrm{u}} \leq \lambda^{\mathrm{d}}$.

Based on the assumptions leading to equation (1) and the additional labor market constraints that undocumented workers face, undocumented workers are expected to draw wage offers from a distribution ( $\mathrm{F}^{\mathrm{u}}[\mathrm{w}]$ ) that is stochastically dominated by the wage offer distribution that documented workers face $\left(\mathrm{F}^{\mathrm{d}}[\mathrm{w}]\right)$, implying that at any given wage, $\tilde{\mathrm{w}}$, $\mathrm{F}^{\mathrm{d}}[\tilde{\mathrm{w}}] \leq \mathrm{F}^{\mathrm{u}}[\tilde{\mathrm{w}}]$, or $\operatorname{Pr}\left[\mathrm{W}^{\mathrm{d}} \leq \tilde{\mathrm{w}}\right] \leq \operatorname{Pr}\left[\mathrm{W}^{\mathrm{u}} \leq \tilde{\mathrm{w}}\right]$. The lower offer arrival rate and stochastically inferior wage distribution lead to the result that for any given wage, $\tilde{\mathbf{w}}$, the separation rate among undocumented workers is lower than among documented workers: ${ }^{16}$

\footnotetext{
${ }^{15}$ See Burdett and Mortensen (1988), Manning (2003, sections 2.2 and 4.4), and Ransom and Oaxaca (2007). The basic assumptions of the model are that firms have identical constant returns to scale, workers are identical, each worker has the same value of leisure, some workers are employed and others are unemployed, and workers can search while employed. The main implication from the equilibrium search model (that is relevant for this paper) is that the firm has to offer a higher wage to attract more workers. Also see Jovanovic (1979) whose job matching model also predicts that workers paid a higher wage are less likely to separate from their employers.

${ }^{16}$ This result only requires one of the two conditions--lower offer arrival rate or stochastically inferior wage offer distribution--but it is not unreasonable to expect both of these conditions to be satisfied.
} 


$$
\mathrm{S}^{\mathrm{u}}\left(\tilde{\mathrm{w}} ; \mathrm{F}^{\mathrm{u}}[\tilde{\mathrm{w}}]\right) \leq \mathrm{S}^{\mathrm{d}}\left(\tilde{\mathrm{w}} ; \mathrm{F}^{\mathrm{d}}[\tilde{\mathrm{w}}]\right)
$$

This result is consistent with DeFreitas (1988) who finds that Hispanic immigrants (although not necessarily undocumented) do not exhibit higher turnover tendencies than documented workers when comparing equally skilled workers in the same sectors. The ability of firms to exploit their monospony power is predicated not on how often workers separate, but on how sensitive that separation behavior is to changes in the wage. Constructing the elasticity of separation allows a comparison of workers' sensitivity to wage changes abstracting from expected wage level of the workers.

From equation (2), the elasticity of separation with respect to the wage for worker of type $k$, evaluated at the expected wage for that worker type $\left(\bar{w}^{k}\right)$ is:

$$
\left.\varepsilon_{S w}^{k}\right|_{w=\bar{w}^{k}}=\left.\left\{\frac{\partial S^{k}\left[w ; F^{k}(w)\right]}{\partial w} \frac{w}{S^{k}(w)}\right\}\right|_{w=\bar{w}^{k}}=\left.\frac{-\lambda^{k} f^{k}[w] w}{S^{k}(w)}\right|_{w=\bar{w}^{k}}<0 .
$$

In general, for which group of workers the elasticity is larger cannot be determined analytically; the shape of the wage offer density function relative to the expected wage for each group will ultimately determine the relative sizes of the elasticity. The point is, knowing that the wage offer distribution of documented workers stochastically dominates the wage offer distribution of undocumented workers indicates that the separation rate of documented workers exceeds that of undocumented workers (within the framework of this simple search model and at a given wage). However, it does not tell us how sensitive the workers will be to wage changes, relative to one another.

\section{B. Elasticities of Labor Supply}

A technique suggested by Ransom and Oaxaca (2008) is used to estimate the labor supply elasticity of documented and undocumented workers based on estimates of workers' separation 
elasticities (also see Barth and Dale-Olsen 2009). ${ }^{17}$ This technique relies on two assumptions. First, it requires that the flow of recruits (or new hires) equals the flow of separations; that one employer's separation is another employer's recruitment. This assumption would not necessarily be valid in circumstances of very weak labor markets. The years 1995-2000 are the years in the data that could be considered to satisfy this requirement. Each year during this time period, the percent of workers that is separating and the percent of workers being hired differ by, at most, three percentage points, except for the subset of undocumented workers with ITIN numbers, where the difference can be slightly greater. ${ }^{18}$ However, among all groups of workers over this time period, the percent being hired always exceeds the percent separating.

A second assumption is required as a result of how undocumented workers are identified. Since undocumented workers are defined as those using certain types of invalid SSNs, it is not reasonable to expect that an undocumented worker would use the same SSN when moving from one employer to another. Consequently, the worker's SSN cannot be used as a worker fixed effect within the undocumented sample. A worker fixed effect is constructed by combining the worker's SSN and the employer id number (SSN/EMPID) so that multiple observations within an employer are treated as observations from the same person, but the same SSN across employers will be treated as different workers. ${ }^{19}$ This is less than ideal, but necessary to boost the number of undocumented observations. The presence of ITIN numbers, however, does provide a type of robustness check on the results. The analysis will be repeated for the years 1997 (the first year

\footnotetext{
${ }^{17}$ As they point out, it is much easier to estimate the elasticity of separation than it is to estimation the elasticity of labor supply (or elasticity of recruitment). Bhaskar et al. (2002) also make use of estimated separation elasticities to make inferences about employer monopsony power, emphasizing that the focus on separation elasticities is not a focus on the level of turnover, but on the sensitivity of those separations to the wage. Also see Barth and DaleOlsen (2009) who exploit the same relationship in a firm-level analysis of labor supply elasticity differences between men and women.

${ }^{18}$ The average annual separation and new hire rates are only statistically significantly different from each other among documented workers at the 90 percent confidence level.

${ }^{19}$ Barth and Dale-Olsen (2009) construct a similar "worker/work-place" fixed effect for their analysis.
} 
ITIN numbers were issued) through 2000, with the undocumented worker sample restricted to workers whose reported SSN matches the ITIN number scheme. Then the SSN by itself will be used as the worker fixed effect, assuming that undocumented workers with ITIN numbers will use the same number across employers. The problem that arises with this specification is a lack of degrees of freedom; workers with ITIN numbers represent only about two percent of the entire undocumented worker sample and requiring at least two observations per worker cuts the sample even more. The results generally lead to the same conclusions regarding labor supply elasticities as those reported using the SSN/EMPID fixed effect.

Given these considerations, the labor supply elasticity can be estimated as the negative of two times the separation elasticity (see Ransom and Oaxaca 2008, p. 4):

$$
\varepsilon_{n w}^{k}=-2 \varepsilon_{s w}^{k}>0,
$$

with equation (4) implying that $\varepsilon_{n w}^{u} \leq \varepsilon_{n w}^{d}$.

Workers' separation elasticities, then, are estimated by first estimating the following linear probability separation equation separately for documented workers $(k=d)$ and for undocumented workers $(k=u):^{20}$

$S_{\text {injt }}=\gamma_{0}^{k}+\gamma_{1}^{k} \ln \left(w_{\text {injt }}\right)+\gamma_{2}^{k} h_{n t}+\gamma_{3}^{k} X_{\text {injt }}+\gamma_{4}^{k} Y Q_{t}+\delta_{i}+\varepsilon_{\text {injt }}$

where $S_{\text {injt }}$ is the probability that worker $i$ separates from employer $n$ (in industry $j$ ) in quarter $t$;

$w_{i n j t}$ is the real quarterly wage observed for worker $i$ in quarter $t ; h_{n t}$ is the percent of new hires in firm $n$ that are undocumented; and $X_{\text {injt }}$ are other characteristics of the worker, firm, industry at time $t$ that might affect the rate of separation. $Y Q_{t}$ is a continuous regressor defined as Y.Q,

\footnotetext{
${ }^{20}$ There is a class of workers that have invalid SSNs but does not meet our criteria for "undocumented." These workers are described in Section II.B. and are excluded from both the documented and undocumented worker samples. A linear probability model is estimated as opposed to a probit model because of the large number of fixed effects included.
} 
where year $\mathrm{Y} \in[97,100]$ and quarter $\mathrm{Q} \in[00,75] .{ }^{21} \delta_{i}$ is the individual fixed effect defined as the worker's reported SSN. The percent of new hires in firm $n$ at time $t$ that are undocumented is calculated as $h_{n t}=100 *\left[H_{n t}^{u} /\left(H_{n t}^{u}+H_{n t}^{d}\right)\right]$, where $H^{k}$ is the number of undocumented $(k=u)$ and documented $(k=d)$ workers hired by the firm during the previous four quarters.

In order to control for the possibility that undocumented workers are drawn to industries experiencing a rising relative demand for their skills or to industries that have a history of hiring undocumented workers (see Card and DiNardo 2000), the share of workers in the 6-digit NAICS industry that are undocumented is also included as a regressor. The standard errors will be adjusted for clustering at the firm level, since multiple workers may be employed by the same firm. A worker is considered separated if the worker's SSN disappears from the employer's files for at least four consecutive quarters.

In addition to the regressors of particular interest, worker tenure is included and is expected to be negatively related to worker separation (Jovanovic 1979). The age and size of the worker's firm and the churning of workers by the firm are expected to affect observed individual separations (Burgess et al. 2001); ${ }^{22}$ both older and larger firms are expected to have hiring mechanisms in place to generate more successful hires, thus less separation. County level unemployment rate is also included to control for general local labor market conditions. ${ }^{23}$

Given the estimation results from equation (5), the average separation elasticity with respect to wages for workers of type $k$ can be calculated as follows:

\footnotetext{
${ }^{21}$ A continuous regressor is chosen for parsimony; using dichotomous year and quarter indicators does not alter conclusions presented here.

22 Churning is measured as the difference between worker flows and job flows divided by the average employment during the period. Worker flows is the sum of hires and separations and job flows is net employment change. CHURN $N_{j t}=\frac{[\text { Hires }+ \text { Separations }]-\left[\left|N_{j t}-N_{j t-1}\right|\right]}{\left[\left(N_{j t}+N_{j t-1}\right) / 2\right]}, N_{t}$ is the number of workers in time $t$ (Burgess et al. 2001).

${ }^{23}$ Due to limited degrees of freedom among the undocumented worker sample, we've included what we consider the bare minimum regressors. Additional regressors were investigated, such as county level firm birth and death rates and a measure of market competitiveness; their inclusion did not change the results on the regressors of interest or the conclusions presented here.
} 


$$
\bar{\varepsilon}_{s w}^{k}=\frac{1}{N^{k}} \sum_{i=1}^{N^{k}} \frac{\partial s}{\partial w} \frac{w_{i}}{s_{i}}=\frac{1}{N^{k}} \hat{\gamma}_{1}^{k} \sum_{i=1}^{N^{k}} \frac{1}{s_{i}},
$$

where $N^{k}$ is the total number of workers of type $k$ (Ransom and Oaxaca 2008, p. 12). The average labor supply elasticity for workers of type $k$, then, from equation (4), is $\bar{\varepsilon}_{n w}^{k}=-2 \bar{\varepsilon}_{s w}^{k}$.

To the extent that the arrival of undocumented workers depresses wages in a labor market or results in employers substituting documented workers with undocumented workers, an outflow of documented workers is expected. This potential outflow could not only affect estimates of the wage impact, but could also have considerable social welfare impacts if documented workers were flowing into unemployment (rather than to merely another job). The impact of undocumented worker inflow on separation behavior can also be investigated using the estimates obtained from equation (5). The average separation elasticity with respect to the share of new hires that is undocumented is calculated as:

$$
\bar{\varepsilon}_{s h}^{k}=\frac{1}{N^{k}} \sum_{i=1}^{N^{k}} \frac{\partial s}{\partial h} \frac{h_{i}}{s_{i}}=\frac{1}{N^{k}} \hat{\gamma}_{2}^{k} \sum_{i=1}^{N^{k}} \frac{h_{i}}{s_{i}} .
$$

The average separation elasticity with respect to the hiring of undocumented workers gives us some indication of the degree of displacement taking place. Documented workers may voluntarily separate from their employers as wages are driven lower or in anticipation of losing their jobs down the road. Involuntary displacement would be the direct replacement of documented workers with undocumented workers. The analysis, however, will not be able to distinguish between the types of displacement. 


\section{$\underline{\text { IV. Results }}$}

\section{A. Full Sample}

Table 3 contains the OLS fixed-effects linear probability estimates for equation (5), estimated for the full sample of individuals from 1995 through 2000, using the combined SSN/EMPID as the worker fixed effect. Estimates are presented for documented and undocumented workers separately.

\section{[Table 3 here]}

As expected, higher paid workers and workers with longer tenure have lower probabilities of separation. Workers employed at older, smaller, and firms with more workforce churning are more likely to separate. The share of workers in the industry that is undocumented does not appear to affect individual separation rates, but the greater the share of new hires that is undocumented at the firm increases workers' separation. Although only significant among documented workers, the greater the county level unemployment rate, the less likely a worker is to separate, which is consistent with worker effort models (for example, see Machin and Manning 1992).

The parameter estimate on log wage is transformed into an average labor supply elasticity and reported at the bottom of the table. As hypothesized, undocumented workers are less sensitive (about 13 percent less sensitive) to wage changes than documented workers (the differences are more dramatic among different groups of workers as will be discussed below). A one percent decrease in the wage reduces the supply of undocumented workers by 0.49 percent, but reduces the supply of documented workers by 0.57 percent. $^{24}$ In other words, documented

\footnotetext{
${ }^{24}$ While the focus here is not on the actual point estimate, but rather their relative size across worker status, these labor supply elasticities are within the range of those estimated by others. For example, Costa (2000) estimated cross-sectional labor supply elasticities for men and women of 0.04 and 0.13 , respectively; Benjamin et al. (2007) estimated an elasticity of 0.24 for real estate brokers. Bhaskar et al. (2002) report elasticities that would be in the
} 
workers are more likely than undocumented workers to quit their jobs in response to a wage reduction.

In addition, newly arriving undocumented workers appear to have a greater impact on displacing earlier arriving undocumented workers than on displacing documented workers. A one percent increase in the share of new hires that are undocumented increases the separation of documented workers by only 0.001 percent and undocumented workers by 0.03 percent. This result is consistent with that of Ottaviano and Peri (2006) and Lalonde and Topel (1991) who find that the arrival of immigrants negatively impacts the labor market outcomes of earlier arrivals more than those of natives.

\section{B. Estimates Across Income Groups and Sectors}

Estimated elasticities for the full sample might be masking more dramatic differences within subsets of workers. Labor supply elasticities estimated separately across wage groups and broad industry characteristics are reported in the first two columns of Table 4 and they tell a remarkably consistent story. With only a very few exceptions, undocumented workers are significantly less sensitive to wage changes than documented workers. Undocumented workers are also consistently more likely to be displaced by newly arriving undocumented workers than are documented workers; the displacement elasticity estimates across worker groups are found in the first two columns of Table 5.

\section{[Tables 4 and 5 here]}

Across both types of workers, the elasticity of labor supply increases in the wage level, with higher paid workers more sensitive to wage changes than lower paid workers, then decreases (becomes negative among documented workers) at the highest wage level. This

range of 0.7 and 1.2. Ransom and Oaxaca (2007), in their single-firm study, estimated elasticities close to 2.0 for both men and women. 
pattern of elasticities across wage groups is indicative of a labor supply curve that starts out concave then has a transition point between the third and fourth quartile. Although not significant, a negative labor supply elasticity among documented workers is consistent with a backward bending labor supply curve found by others among higher income workers (e.g., Hall 1973). ${ }^{25}$ Comparing elasticities across quartiles, it appears that the overall weaker sensitivity to wage changes among undocumented workers is being driven by the behavior of workers in the bottom half of the wage distribution, which is where most undocumented workers find themselves.

Across broad sector classifications and grouping workers by their industry's skill level, undocumented workers are less sensitive to wage changes than documented workers, with the only exception being construction and leisure and hospitality. These are notable given the relatively large representation of undocumented workers in those sectors. However, Yueh (2008) presents evidence suggesting that workers with larger social networks will exhibit greater labor supply elasticities (ceteris paribus) than those with smaller social networks, and we would expect this "social network" effect to be strongest in sectors with a larger concentration of undocumented workers, such as construction and leisure and hospitality.

Another notable difference is that documented workers become more sensitive as skill intensity increases, but undocumented workers become less sensitive. This may be because the number of higher skill job opportunities are fewer and far between than low skill job opportunities for undocumented workers.

\footnotetext{
${ }^{25}$ This pattern of increasing, then decreasing labor supply elasticities across income quartiles is also consistent with own wage elasticities estimated by Hotchkiss and Moore (2007) across education levels.
} 


\section{Robustness Check}

Using the combined SSN and employer id for the worker fixed effect we lose the link between workers across employers. In order to see whether this sacrifice affects the basic conclusions, the separation equation was re-estimated including only those undocumented workers whose SSN matches the ITIN number scheme, on the assumption that if a worker is using an ITIN number, he/she will use it across multiple employers. The years are restricted to 1997 through 2000 since 1997 is the first year ITIN numbers were issued. The sample of undocumented workers is reduced substantially from over 100,000 observations to about 1,300 observations. The results of these estimations across worker groups are reported in the last two columns of Tables 4 and 5.

For the full samples, there is a greater difference in the labor supply elasiticities across worker status, with a one percent decrease in the wage increasing separation among documented workers by 0.62 percent, but among undocumented workers by only 0.48 percent. Except for the first quartile of wages, the first category of skill intensity, retail trade, and the leisure and hospitality sector, all other estimates of the labor supply elasticities (that are significantly different from zero) reinforce the conclusion that undocumented workers are less sensitive to wage changes than documented workers. Generally, the year restriction and use of the SSN fixed effect (as opposed to the combined SSN/EMPID) does not affect the general magnitudes or significance levels of these estimated elasticities. In addition, the basic pattern of elasticities across different worker and industry characteristics (wage quartiles, skill intensity, etc.) are the same.

The estimates of elasticities of separation with respect to new hires are pretty much all over the board and most insignificant for this restricted sample of undocumented workers. 
Among documented workers, the different years of analysis and use of the SSN as a fixed effect (as opposed to the combined SSN/EMPID) does not generally affect the magnitude or significance levels of these estimated elasticities.

\section{$\underline{\text { V. Implications and Conclusions }}$}

The analysis in this paper presents evidence of employer monopsony power in the labor market for undocumented workers. The limited employment and grievance opportunities of undocumented workers makes this an un-surprising result, however this finding has implications for firm profits and product prices. Firms who enjoy a monopsony position in the labor market also enjoy greater profits from being able to pay at least some of its workers a wage lower than their marginal revenue product. These firms may not take kindly to efforts to limit their supply of inexpensive labor through stricter immigration policies. In addition, if those policies were successful in limiting the supply of undocumented workers, resulting in higher production costs; consumers may see the effect in the form of higher product prices (see Cortes 2008).

Alternatively, if policies were focused on eliminating the monopsony position of employers, and employers paid all workers a wage equal to their marginal revenue product, they would be indifferent between hiring documented and undocumented workers. While this may not seem like a boon to documented workers, they would now be competing with undocumented workers on skill and human capital rather than on a willingness to be paid less than their actual contribution to the firm's output. Eliminating the firm's monopsony power would require somehow legitimizing the presence of workers who are now considered undocumented. One way to do this would be to create a permeable border, allowing the flow of workers to be dictated by the demand of employers through something like a guest-worker program. Facilitating an 
employers' ability to draw workers from a larger pool when needed would likely have to be accompanied by strictly enforced penalties for hiring workers outside of the guest-worker program. Of course, policy makers may have other goals in mind, such as ensuring the highest wage possible for U.S. citizens. If this is the case, the implications for immigration policy would look very different. 


\section{References}

Barth, Erling, and Harald Dale-Olsen, "Monopsonistic Discrmination and the Gender-wage Gap," NBER Working Paper No. W7197, June 1999.

Barth, Erling, and Harald Dale-Olsen, "Monopsonistic Discrmination, Worker Turnover, and the Gender-wage Gap," IZA Discussion Paper No. 3930, January 2009.

Benjamin, J.D.; P. Chinloy; G.D. Jud; and D.T. Winkler. "Do Some People Work Harder than Others? Evidence from Real Estate Brokerage." Journal of Real Estate Finance and Economics 35(1) (July 2007): 95-110.

Bhaskar, V., Alan Manning, and Ted To, "Oligopsony and Monopsonistic Competition in Labor Markets," Journal of Economic Perspectives, 16(2), 155-74, Spring 2002.

Bovbjerg, Barbara D. 2006. Social Security Numbers: Coordinated Approach to SSN Data Could Help Reduce Unauthorized Work, Testimony before the Subcommittees on Social Security and on Oversight, Committee on Ways and Means, House of Representatives, GAO-06-458T, http://www.gao.gov/new.items/d06458t.pdf, (accessed 15 December 2008).

Brown, J. David; Julie L. Hotchkiss; and Myriam Quispe-Agnoli. "Undocumented Worker Employment and Firm Survival." Federal Reserve Bank of Atlanta Working Paper \#2008-28 (December 2008).

Burdett, Kenneth and Dale T. Mortensen. "Wage Differentials, Employer Size, and Unemployment." International Economic Review 39(2) (1988): 257-73.

Burgess, Simon; Julie Lane; and David Stevens. "Churning Dynamics: An Analysis of Hires and Separations at the Employer Level." Labour Economics 8 (2001): 1-14.

Card, David and John DiNardo. "Do Immigrant Inflows Lead to Native Outflows?" American Economic Review Papers and Proceedings 90 (2) (May 2000), 360-7.

Committee on Ways and Means, House of Representatives. 2004. Greenbook, WMCP 108-6, Section 4, (April).

Cortes, Patricia. "The Effect of Low-skilled Immigration on U.S. Prices: Evidence from CPI Data." Journal of Political Economy 116(3) (2008): 381-22.

Costa, Dora L. "The Wage and the Length of the Work Day: From the 1890s to 1991." Journal of Labor Economics 18(1) (January 2000): 156-81.

DeFreitas, Gregory. "Hispanic Immigration and Labor Market Segmentation." Industrial Relations 27(2) (Spring 1988): 195-214. 
Ethier, Wilfred J. "Illegal Immigration: The Host-country Problem." The American Economic Review 76(1) (March 1986): 56-71.

Fortuny, Karina; Randy Capps; and Jeffrey S. Passel. "The Characteristics of Unauthorized Immigrants in California, Los Angeles County, and the United States." Mimeo. Washington, D.C.: The Urban Institute (March 2007).

Hall, Robert E. "Wages, Income, and Hours of Work in the U.S. Labor Force." In Glen G. Cain and Harold W. Watts, eds. Income Maintenance and Labor Supply, pp. 102-62. Madison, WI: Institute for Research on Poverty, 1973.

Hirsch, Boris, Thorsten Schank, and Claus Schnabel, "Gender Differences in Labor Supply to Monopsonistic Firms: An Empirical Analysis Using Linked Employer-Employee Data from Germany," Friedrich-alexander-Universitat Erlangen-Nurnberg Discussion Papers No. 47, November 2006.

Hoefer, Michael; Nancy Rytina; and Christopher Campbell. "Estimates of the Unauthorized Immigrant Population Residing in the United States: January 2006." Population Estimates. Washington, D.C.: US Department of Homeland Security, Office of Immigration Statistics (August 2007).

Hoefer, Michael; Nancy Rytina; and Bryan C. Baker. "Estimates of the Unauthorized Immigrant Population Residing in the United States: January 2008." Population Estimates. Washington, D.C.: US Department of Homeland Security, Office of Immigration Statistics (February 2009).

Hotchkiss, Julie L. and Robert E. Moore. "Assessing the Welfare Impact of the 2001 Tax Reform on Dual-Earner Families." FRBA Working Paper 2007-27 (December 2007).

Hotchkiss, Julie L. and Myriam Quispe-Agnoli. "The Impact of Undocumented Workers on Documented Worker Wages." Federal Reserve Bank of Atlanta Working Paper \#2009$X X$ (forthcoming 2009).

Jovanovic, Boyan. "Job Matching and the Theory of Turnover." The Journal of Political Economy 87(5, part 1) (October 1979): 972-90.

Lalonde, Robert and Robert Topel. "Labor Market Adjustments to Increased Immigration." In J. Abowd and R. Freeman, eds. Immigration, Trade, and the Labor Market, 167-200. Chicago: University of Chicago Press, 1991.

Lang, Kevin; Michael Manove; and William R. Dickens. "Racial Discrimination in Labor Markets with Posted Wage Offers." American Economic Review 95(4) (September 132740).

Machin, Stephen and Alan Manning. "Testing Dynamic Models of Worker Effort." Journal of Labor Economics 10(3) (July 1992): 288-305. 
Manning, Alan. Monopsony in Motion. Princeton: Princeton University Press, 2003.

Morales, Rebecca. “Transitional Labor: Undocumented Workers in the Los Angeles Automobile Industry,” International Migration Review, 17(4), (1983-1984): 570-596.

Ottaviano, Gianmarco I.P. and Giovanni Peri. "Rethinking the Effects of Immigration on Wages." NBER Working Paper \#12497 (August 2006).

Ofek, Haim and Yesook Merrill. "Labor Immobility and the Formation of Gender Wage Gaps in Local Markets." Economic Inquiry 35 (January 1997): 28-47.

Pedace, Roberto. "Immigration, Labor Market Mobility and the Earnings of Native-born Workers: An Occupational Segmentation Approach." American Journal of Economics and Sociology 65(2) (April 2006): 313-45.

Ransom, Michael R. and Ronald L. Oaxaca. "New Market Power Models and Sex Differences in Pay." Mimeo, Brigham Young University (November 2007).

Raphael, Steven and David Riker. "Geographic Mobility, Race, and Wage Differentials." Journal of Urban Economics 45 (January 1999): 17-46.

Rivera-Batiz, Franciso. "Undocumented Workers in the Labor Market: An Analysis of the Earnings of Legal and Illegal Mexican Immigrants in the United States." Journal of Population Economics 12(1) (February 1999): 91-116.

Robinson, Joan, The Economics of Imperfect Competition. Macmillan: London, 1933.

Scott, Frank A. Jr.; James E. Long; and ken Somppi. "Salary vs. Marginal Revenue Product under Monopsony and Competition: The Case of Professional Basketball." Atlantic Economic Review 13(3) (September 1985): 50-9.

Scully, Gerald W. The Business of Major League Baseball. Chicago: University of Chicago Press, 1989.

Semple, Kirk. 2008. "With Economy, Day Laborer Jobs Dwindle." nytimes.com (20 October), $<$ http://www.nytimes.com/2008/10/20/nyregion/20laborers.html?partner=rssnyt $>$, (accessed 20 October 2008).

Stark, Oded. 2007. "Work Effort, Moderation in Expulsion, and Illegal Migration." Review of Development Economics 11 no. 4 (February): 585-90.

U.S. Department of Labor, Employment and Training Administration, "Comparison of State Unemployment Laws,"

<http://workforcesecurity.doleta.gov/unemploy/uilawcompar/2008/comparison2008.asp> (accessed 10 December 2008). 
U.S. Department of Housing and Urban Development. "Disclosure and Verification of Social Security Numbers (SSNs) for the Section 235 Program." Mortgagee Letter 90-39 (9 November 1990).

<http://209.85.165.104/search?q=cache:5VRIgv1oFQYJ:www.fha.gov/reference/ml1990 /90-39ml.doc+pocketbook+social+security+numbers\&hl=en\&ct=clnk\&cd=9\&gl=us $>$ (accessed 20 September 2007).

Yueh, Linda Y. "Do Social Networks Increase Labour Supply Elasticities." Applied Economics Letters 15 (2008): 5-10.

Zimbalist, Andrew. Baseball and Billions. New York: Basic Books, 1992. 
Figure 1.

Percent of workers with invalid SSN, by reason, construction, 1990:1 - 2006:4

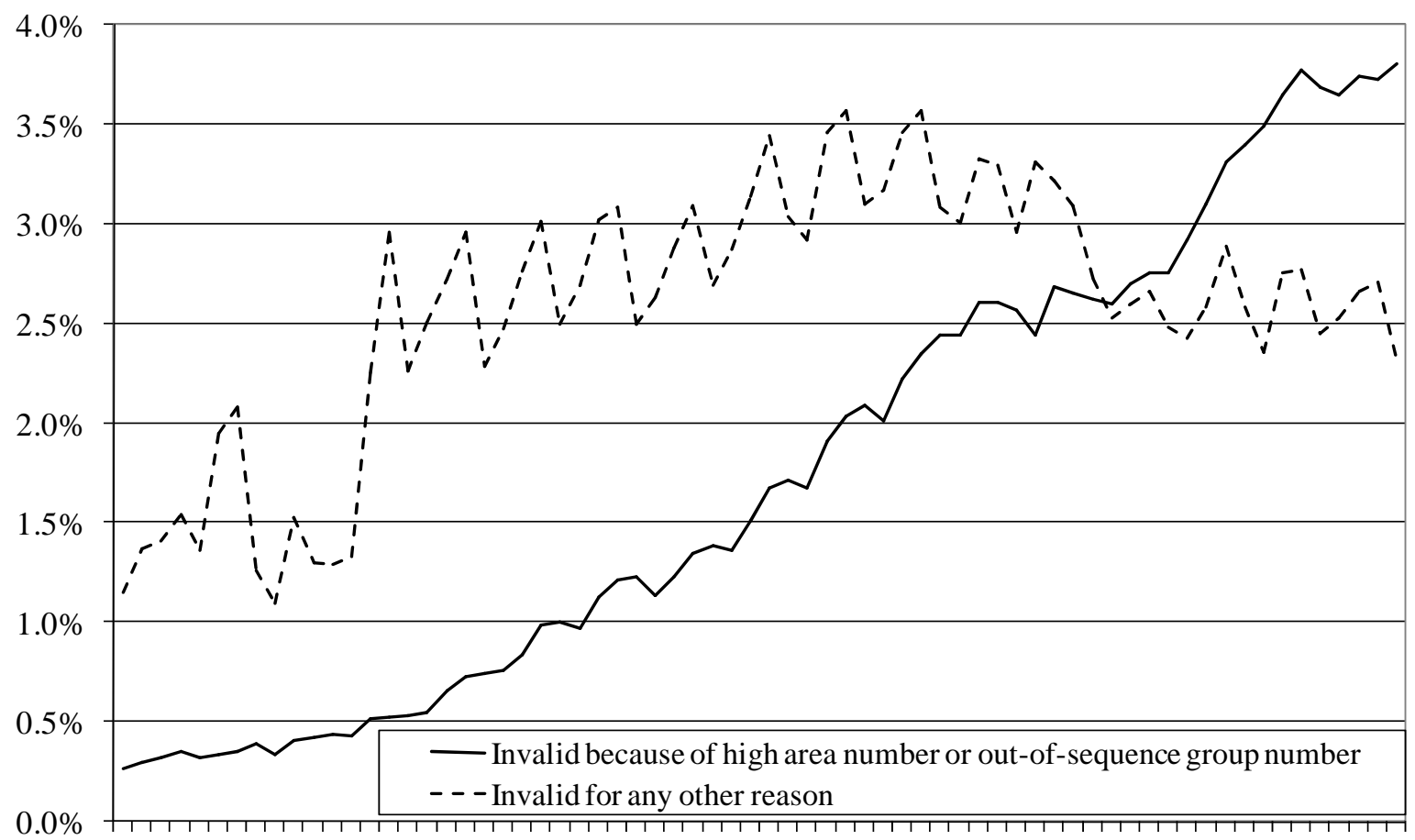

19901991199219931994199519961997199819992000200120022003200420052006

Figure 2.

Percent of workers that is undocumented by broad industry, 1990:1 - 2006:4

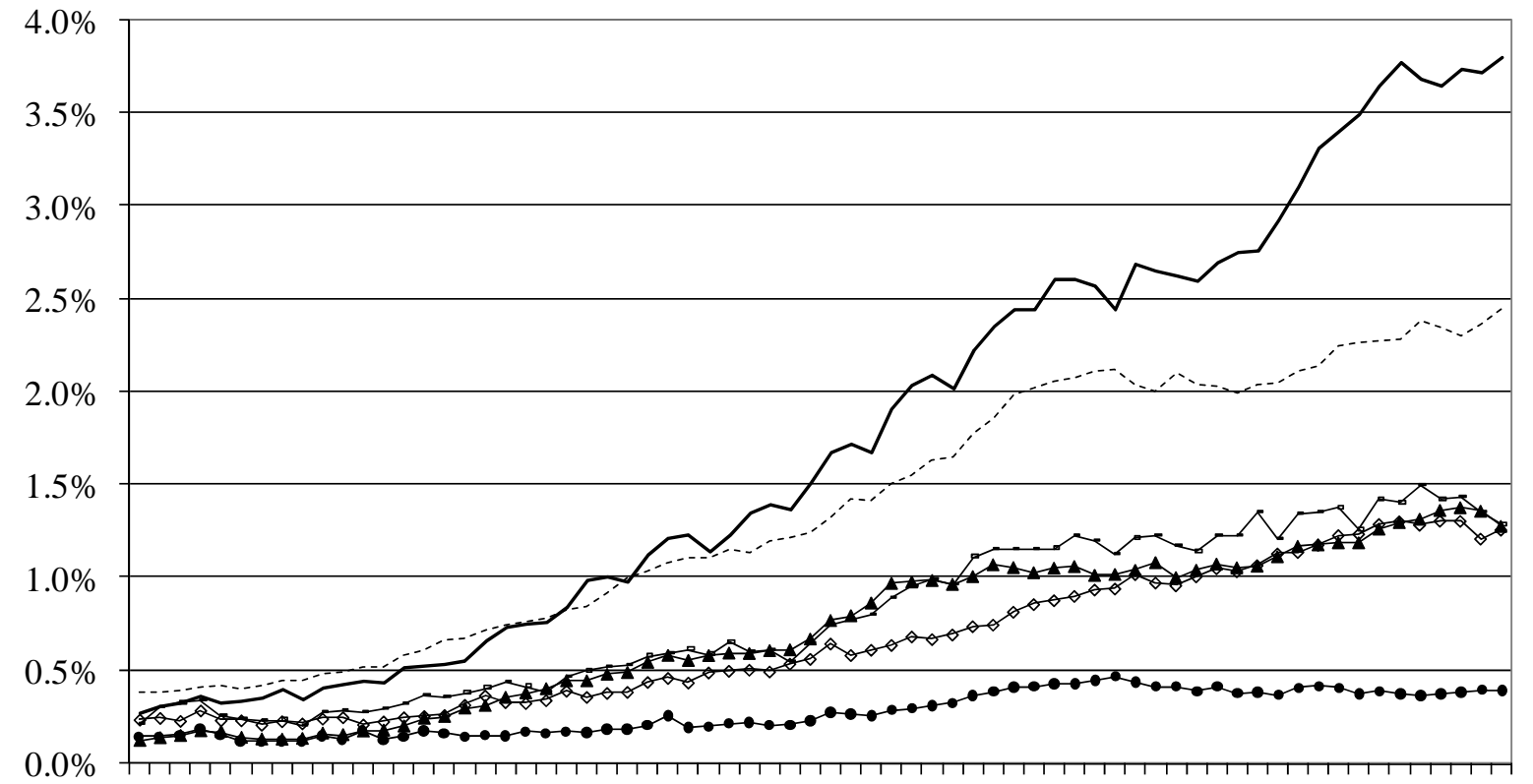

19901991199219931994199519961997199819992000200120022003200420052006

\begin{tabular}{|c|c|c|}
\hline - Construction & ---- Leisure and Hospitality & $\smile$ Manufacturing \\
\hline$\multimap$ Other Services & $\longrightarrow$ Prof. and Business Srvcs & $\multimap$ Retail Trade \\
\hline
\end{tabular}


Figure 3. Growth in the earnings suspense file and the total number and percent of workers identified as undocumented in Georgia, 1990-2006.
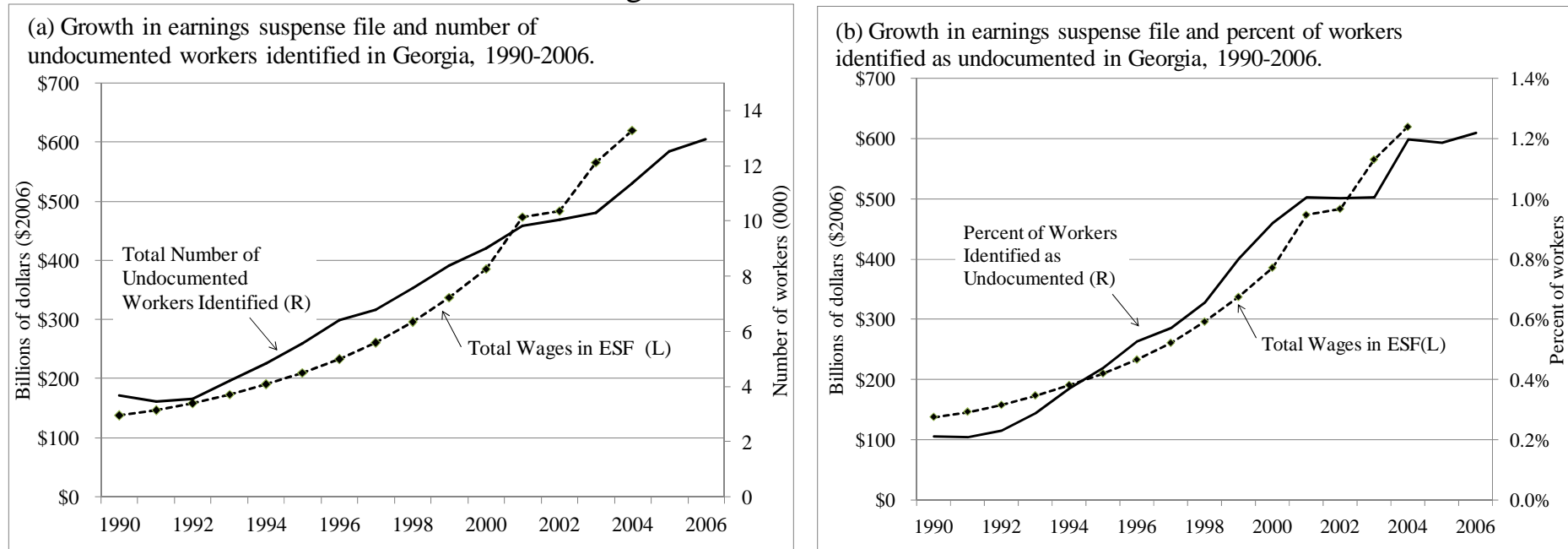

Source: Huse (2002) for estimates 1990-2000, Johnson (2007) for estimates 2001-2004, and authors' calculations. Dollar estimates reflect 2006 values, using the PCE chain-weighted deflator.

Table 1. Correlation between percent of workers identified as undocumented by county and the percent of firms that employ them, with the percent of the population in each county that is Hispanic, African American, and Asian.

\begin{tabular}{lcc}
\hline Percent of Population that is: & $\begin{array}{c}\text { Percent of Undocumented } \\
\text { Workers in County }\end{array}$ & $\begin{array}{c}\text { Percent of Firms Employing } \\
\text { Undocumented Workers } \\
\text { in County }\end{array}$ \\
\hline \hline Hispanic & 0.18 & 0.38 \\
Asian & -0.02 & 0.27 \\
African American & -0.19 & -0.13 \\
\hline
\end{tabular}


Table 2. Sample means.

\begin{tabular}{|c|c|c|c|}
\hline & $\begin{array}{c}\text { Documented } \\
1995-2000\end{array}$ & $\begin{array}{l}\text { Undocumented } \\
1995-2000\end{array}$ & $\begin{array}{c}\text { Undocumented } \\
\text { 1997-2000 } \\
\text { ITIN only } \\
\end{array}$ \\
\hline Wage & $\begin{array}{l}\$ 4,961 \\
(12081)\end{array}$ & $\begin{array}{l}\$ 3,272 \\
(7247)\end{array}$ & $\begin{array}{l}\$ 3,500 \\
(5421)\end{array}$ \\
\hline First wage quartile range & {$[1-566]$} & {$[1-477]$} & [3-598] \\
\hline Second wage quartile range & {$[567-1,969]$} & {$[478-1,675]$} & {$[600-2,011]$} \\
\hline Third wage quartile range & {$[1,970-5,299]$} & {$[1,676-4,199]$} & {$[2,018-4,839]$} \\
\hline Fourth wage quartile range & {$[5,300-1,280,235]$} & {$[4,200-239,197]$} & {$[4,840-84,676]$} \\
\hline Worker tenure (number of quarters) & $\begin{array}{c}3.20 \\
(5.42)\end{array}$ & $\begin{array}{c}1.66 \\
(1.83)\end{array}$ & $\begin{array}{c}1.65 \\
(1.43)\end{array}$ \\
\hline Percent of workers separating & $52 \%$ & $69 \%$ & $62 \%$ \\
\hline Percent of workers newly hired & $55 \%$ & $71 \%$ & $67 \%$ \\
\hline $\begin{array}{l}\text { Share of new hires in firm } \\
\text { undocumented }\end{array}$ & $1.2 \%$ & $11.4 \%$ & $15.8 \%$ \\
\hline $\begin{array}{l}\text { Share of workers in 6-digit NAICS } \\
\text { industry undocumented }\end{array}$ & $1.3 \%$ & $3.23 \%$ & $3.68 \%$ \\
\hline Age of employer (number of quarters) & $\begin{array}{c}25.8 \\
(11.6)\end{array}$ & $\begin{array}{c}24.5 \\
(12.4)\end{array}$ & $\begin{array}{c}25.3 \\
(13.8)\end{array}$ \\
\hline Employer size (number of workers) & $\begin{array}{l}2,260 \\
(5365)\end{array}$ & $\begin{array}{l}1,175 \\
(2943)\end{array}$ & $\begin{array}{c}1,254 \\
(3808)\end{array}$ \\
\hline $\begin{array}{l}\text { Worker churning at place of } \\
\text { employment (documented wrkrs only) }\end{array}$ & $56 \%$ & $65 \%$ & $63 \%$ \\
\hline \multicolumn{4}{|l|}{ Distribution by skill intensity } \\
\hline Low skill & $20 \%$ & $33 \%$ & $32 \%$ \\
\hline Medium skill & $67 \%$ & $61 \%$ & $63 \%$ \\
\hline High skill & $13 \%$ & $6 \%$ & $5 \%$ \\
\hline \multicolumn{4}{|l|}{ NAICS Sector Shares } \\
\hline Natural Resources and Agriculture & $1 \%$ & $8 \%$ & $7 \%$ \\
\hline Construction & $6 \%$ & $12 \%$ & $18 \%$ \\
\hline Manufacturing & $11 \%$ & $14 \%$ & $9 \%$ \\
\hline Transportation and Utilities & $3 \%$ & $1 \%$ & $<1 \%$ \\
\hline Wholesale Trade & $3 \%$ & $3 \%$ & $3 \%$ \\
\hline Retail Trade & $17 \%$ & $7 \%$ & $8 \%$ \\
\hline Financial Activities & $4 \%$ & $2 \%$ & $2 \%$ \\
\hline Information & $3 \%$ & $<1 \%$ & $<1 \%$ \\
\hline $\begin{array}{l}\text { Professional and Business Services } \\
\text { (includes temporary services) }\end{array}$ & $23 \%$ & $23 \%$ & $21 \%$ \\
\hline
\end{tabular}




\begin{tabular}{|l|c|c|c|}
\hline Education and Health Services & $7 \%$ & $3 \%$ & $2 \%$ \\
\hline Leisure and Hospitality & $19 \%$ & $23 \%$ & $24 \%$ \\
\hline $\begin{array}{l}\text { Other Services } \\
\text { (includes private household, laundry, } \\
\text { and repair and maintenance services) }\end{array}$ & $3 \%$ & $2 \%$ & $4 \%$ \\
\hline & & & \\
\hline No. of observations & $15,326,269$ & 222,422 & 3,242 \\
\hline
\end{tabular}

Notes: Wages are real quarterly earnings, deflated by the chained price index for personal consumption expenditure \$2006Q4. Standard errors are in parentheses. Numbers in these cells do not reflect number of observations used in estimation as the estimation procedure requires two observations per worker to identify the fixed effect, thus reducing the usable sample size. 
Table 3. OLS fixed-effect linear probability estimates of separation equation.

\begin{tabular}{|l|c|c|}
\hline \multirow{2}{*}{ Variable } & \multicolumn{2}{|c|}{ Full Samples } \\
& Documented & Undocumented \\
\hline Intercept & $1.1906^{*}$ & $1.1365^{*}$ \\
& $(0.0869)$ & $(0.1691)$ \\
\hline $\ln (w)$ & $-0.1585^{*}$ & $-0.1498^{*}$ \\
& $(0.0011)$ & $(0.0018)$ \\
\hline Tenure & $-0.0081^{*}$ & $-0.0387^{*}$ \\
& $(0.0004)$ & $(0.0012)$ \\
\hline Age of employer & $0.0003^{*}$ & $0.0009^{*}$ \\
& $(0.0001)$ & $(0.0002)$ \\
\hline Employer size (\# workers)/ 10000 & $-0.0168^{*}$ & $-0.0201^{\wedge}$ \\
& $(0.0048)$ & $(0.0090)$ \\
\hline Worker churning at place of employment & $0.1497^{*}$ & $0.0952^{*}$ \\
& $(0.0047)$ & $(0.0091)$ \\
\hline \% of workers in industry that is undocumented & -0.0007 & 0.0004 \\
& $(0.0010)$ & $(0.0009)$ \\
\hline Percent of new hires in firm undocumented $(h)$ & $0.0518^{*}$ & $0.1433^{*}$ \\
& $(0.0171)$ & $(0.0159)$ \\
\hline Y.Q & $0.0044^{*}$ & $0.0054^{*}$ \\
\hline County unemployment rate & $(0.0009)$ & $(0.0017)$ \\
\hline & $-0.0016^{\wedge}$ & -0.0023 \\
& $(0.0007)$ & $(0.0016)$ \\
\hline Adjusted R sq. & & \\
\hline Labor supply elasticity $\left(\varepsilon_{n w}\right)$ & 0.31 & 0.31 \\
\hline Separation elasticity wrt \% of new hires undoc $\left(\varepsilon_{\text {sh }}\right)$ & $0.0012^{*}$ & $0.0254^{*}$ \\
\hline No. of Observations & $8,069,046$ & 118,104 \\
\hline
\end{tabular}

Notes: Analysis includes workers employed in Georgia 1995-2000 inclusive. Y.Q is a continuous variable constructed as $\mathrm{Y} \in[97,100]$ and quarter $\mathrm{Q} \in[00,75]$. The worker fixed effect is constructed as a combination of the worker's SSN and worker's employer id number. Standard errors are corrected for clustering at the firm level. ${ }^{*} \Rightarrow$ statistical significance at the 99 percent confidence level; ${ }^{\wedge} \Rightarrow$ statistical significance at the 95 percent confidence level; ${ }^{+} \Rightarrow$ statistical significance at the 90 percent confidence level. 
Table 4. Labor supply elasticities $\left(\varepsilon_{n w}\right)$ by wage quartiles and industry groups, for 1995-2000 samples and for 1997-2000 sample restricted to undocumented workers with ITIN numbering scheme.

\begin{tabular}{|c|c|c|c|c|}
\hline & \multicolumn{2}{|c|}{$\begin{array}{c}1995-2000 \\
\delta_{i}=S S N \mid E M P I D\end{array}$} & \multicolumn{2}{|c|}{$\begin{array}{c}\text { Undocumented workers } \\
\text { restricted to those with ITIN } \\
1997-2000 \\
\delta_{i}=S S N\end{array}$} \\
\hline & Documented & Undocumented & Documented & Undocumented \\
\hline Full Sample & $0.569^{*}$ & $0.494^{*}$ & $0.619^{*}$ & $0.475^{*}$ \\
\hline \multicolumn{5}{|l|}{ Wage Quartiles } \\
\hline Quartile 1 & $0.134^{*}$ & $0.085^{*}$ & $0.131 *$ & $0.261^{*}$ \\
\hline Quartile 2 & $0.689^{*}$ & $0.394^{*}$ & $0.746^{*}$ & 0.191 \\
\hline Quartile 3 & $1.391^{*}$ & $1.732^{*}$ & $2.215^{*}$ & 1.154 \\
\hline Quartile 4 & -0.027 & $0.250^{\wedge}$ & $1.270^{*}$ & -0.379 \\
\hline \multicolumn{5}{|l|}{ Skill Intensity } \\
\hline Low skill & $0.593^{*}$ & $0.516^{*}$ & $0.590 *$ & $0.631 *$ \\
\hline Medium skill & $0.561 *$ & $0.493 *$ & $0.596^{*}$ & $0.460 *$ \\
\hline High skill & $0.687^{*}$ & $0.247^{*}$ & $0.885^{*}$ & neo \\
\hline \multicolumn{5}{|l|}{ NAICS Sector } \\
\hline Natural Resources and Ag. & $0.433^{*}$ & $0.271^{*}$ & $0.420^{*}$ & $0.291^{\wedge}$ \\
\hline Construction & $0.630^{*}$ & $0.635^{*}$ & $0.676^{*}$ & $0.359^{*}$ \\
\hline Manufacturing & $0.884^{*}$ & $0.716^{*}$ & $0.903^{*}$ & $0.878^{*}$ \\
\hline Transportation \& Utilities & $0.681^{*}$ & $0.325^{*}$ & $0.753^{*}$ & neo \\
\hline Wholesale Trade & $0.781^{*}$ & $0.497^{*}$ & $0.978^{*}$ & neo \\
\hline Retail Trade & $0.692^{*}$ & $0.376^{*}$ & 0.695 & $1.024^{+}$ \\
\hline Financial Activities & $0.850^{*}$ & $0.303^{*}$ & $1.117^{*}$ & neo \\
\hline Information & $0.798^{*}$ & 0.135 & $0.930^{*}$ & nеo \\
\hline Professional \& Bus Srvcs & $0.439^{*}$ & $0.399^{*}$ & $0.464^{*}$ & $0.382^{*}$ \\
\hline Education and Health & $0.778^{*}$ & $0.170^{*}$ & $0.893^{*}$ & neo \\
\hline Leisure and Hospitality & $0.578^{*}$ & $0.617^{*}$ & $0.586^{*}$ & $0.803^{*}$ \\
\hline Other Services & $0.536^{*}$ & $0.444^{*}$ & $0.665^{*}$ & пео \\
\hline
\end{tabular}

See notes to Table 3. Confidence level determined by the significance of the underlying estimated parameter coefficient. neo=not enough observations. 
Table 5. Elasticities of separation with respect to undocumented new hires $\left(\varepsilon_{\mathrm{sh}}\right)$ by wage quartiles and industry groups, for 1995-2000 samples and for 1997-2000 sample restricted to undocumented workers with ITIN numbering scheme.

\begin{tabular}{|c|c|c|c|c|}
\hline & \multicolumn{2}{|c|}{$\begin{array}{c}1995-2000 \\
\delta_{i}=S S N \mid E M P I D\end{array}$} & \multicolumn{2}{|c|}{$\begin{array}{c}\text { Undocumented workers } \\
\text { restricted to those with ITIN } \\
1997-2000 \\
\delta_{i}=S S N\end{array}$} \\
\hline & Documented & Undocumented & Documented & Undocumented \\
\hline Full Sample & $0.0019^{*}$ & $0.0258^{*}$ & $0.0009^{\wedge}$ & -0.0210 \\
\hline \multicolumn{5}{|l|}{ Wage Quartiles } \\
\hline Quartile 1 & $0.0011^{*}$ & $0.0078^{*}$ & $0.0005^{+}$ & 0.0298 \\
\hline Quartile 2 & $0.0036^{*}$ & 0.0082 & $0.0025 *$ & 0.0038 \\
\hline Quartile 3 & $0.0032^{*}$ & 0.0069 & $0.0015^{+}$ & $-0.3703^{*}$ \\
\hline Quartile 4 & $0.0022^{\wedge}$ & $0.0766^{*}$ & 0.0005 & $0.3526^{\wedge}$ \\
\hline \multicolumn{5}{|l|}{ Skill Intensity } \\
\hline Low skill & $0.0056^{*}$ & $0.0313^{*}$ & $0.0035^{*}$ & 0.0453 \\
\hline Medium skill & $0.0017 *$ & $0.0230 *$ & $0.0008^{\wedge}$ & -0.0314 \\
\hline High skill & 0.0011 & $0.0381^{\wedge}$ & 0.0002 & neo \\
\hline \multicolumn{5}{|l|}{ NAICS Sector } \\
\hline Natural Resources and Ag. & $-0.0095^{\wedge}$ & $0.0496^{*}$ & $-0.020^{\wedge}$ & -0.0512 \\
\hline Construction & $0.0023^{*}$ & $0.0257^{\wedge}$ & $0.0022^{\wedge}$ & 0.0504 \\
\hline Manufacturing & -0.0001 & 0.0005 & -0.0022 & $0.3395^{\wedge}$ \\
\hline Transportation \& Utilities & $0.0020^{\wedge}$ & 0.0500 & 0.0007 & neo \\
\hline Wholesale Trade & 0.0005 & $0.0718^{\wedge}$ & 0.0009 & neo \\
\hline Retail Trade & $0.0019^{*}$ & $0.0269^{\wedge}$ & $0.0010^{*}$ & 0.0044 \\
\hline Financial Activities & -0.0019 & 0.0315 & $-0.0026^{+}$ & neo \\
\hline Information & -0.0016 & 0.0967 & $-0.0058^{\wedge}$ & neo \\
\hline Professional \& Bus Srvcs & $0.0010^{+}$ & $0.0180^{*}$ & -0.0004 & -0.0126 \\
\hline Education and Health & $0.0023^{*}$ & $0.0556^{\wedge}$ & $0.0015^{+}$ & neo \\
\hline Leisure and Hospitality & $0.0061^{*}$ & $0.0141^{*}$ & $0.0055^{*}$ & 0.0516 \\
\hline Other Services & 0.0004 & 0.0234 & -0.0014 & neo \\
\hline
\end{tabular}

See notes to Table 3 and 4. 


\section{Appendix A: Definition of Sectors}

Table A1: Definitions of sectors based on 2-digit NAIC classifications.

\begin{tabular}{lr}
\hline Sector & $\begin{array}{r}\text { Included } \\
\text { 2-digit NAIC }\end{array}$ \\
\hline Construction & 23 \\
Manufacturing & $31-33$ \\
Transportation and Utilities & $22,48-49$ \\
Wholesale Trade & 42 \\
Retail Trade & $44-45$ \\
Financial Activities & $52-53$ \\
Information & 51 \\
Professional and Business Services (includes temporary services) & $54-56$ \\
Education and Health Services & $61-62$ \\
Leisure and Hospitality & $71-72$ \\
$\begin{array}{l}\text { Other Services } \\
\text { (includes private household, laundry, and repair and maintenance services) }\end{array}$ & 81 \\
\hline
\end{tabular}




\section{Appendix B: Skill Intensity Categories}

Each industry is assigned a skill intensity based on the weighted average of educational attainment of workers in that industry, using the Current Population Survey for 1994. This year was chosen since this is the first year in which the nativity (place of birth) of respondents is reported. For each industry, the percent of workers with less than a high school education (LTHS), a high school education (HS), some college (SCOLL), college degree (COLL), and graduate education (GRAD) is calculated. Skill intensity categories was assigned as follows:

Low Skill $=\left\{\begin{array}{l}1 \text { if LTHS }>H S+\text { COLL } \\ 0 \text { otherwise }\end{array}\right.$

High Skill $=\left\{\begin{array}{l}1 \text { if SCOLL }+ \text { COLL }+ \text { GRAD }>H S+\text { SCOLL } \\ 0 \text { otherwise }\end{array}\right.$

Medium Skill $=\left\{\begin{array}{l}1 \text { if High Skill }=0 \text { and Low Skill }=0 \\ 0 \text { otherwise }\end{array}\right.$

About 23 percent of the industries are classified as high skill, 15 percent at low skill, and 62 percent at medium skill. Some examples of low skill industries include agriculture, some manufacturing, and accommodation and food services. Medium skill industries include construction, retail trade, some manufacturing, some education and health, and arts and entertainment. High skill industries include the information sector, electronic computer manufacturing, the financial sector, and some education and health. 